\title{
Review of recent developments for intra-oral scanners
}

\author{
Jong-Hoon Choi', Young-Jun Lim², Won-Jin Lee 3 , Jung-Suk Han², Seung-Pyo Lee ${ }^{4 *}$ \\ 'Department of Dentistry, School of Dentistry, Seoul National University, Seoul, Republic of Korea \\ 2Department of Prosthodontics and Dental Research Institute, School of Dentistry, Seoul National University, Seoul, Republic \\ of Korea \\ ${ }^{3}$ Department of Oral Maxillofacial Radiology, School of Dentistry, Seoul National University, Seoul, Republic of Korea \\ ${ }^{4}$ Department of Oral Anatomy, School of Dentistry, Seoul National University, Seoul, Republic of Korea
}

Making a model that is an accurate replica of the oral structure requires precision and efficiency. Nowadays, rapid technological advances bring digitalization in dentistry. One of the most important works in digital dentistry is three-dimensional modeling of the oral cavity and digitizing the 3D data. Among the three components of CAD/CAM, (1) data capture component (digitizers), (2) design component (CAD software), (3) manufacturing component (CAM), the basic component that has a significant impact on the other processes is the data capture component, i.e. intra-oral scanners. This literature review discusses the principles and clinical use of intra-oral scanners in dentistry based on recent publications of the past 5 years using the PubMed and Google Scholar databases. (J Dent Rehabil Appl Sci 2015;31(2):112-25)

Key words: intra-oral scanner; digital dental impression; three-dimensional imaging

\begin{abstract}
서론
구강 내의 모습을 재현하는 복제모델을 만드는 것은 치과 진료에서 가장 중요한 과정 중 하나이며, 정확성과 효율성이 동시에 만족되어야 하는 과정이다. 현재 대부 분의 치과에서는 구강 내 모습을 재현할 때 전통적인 인 상채득방법을 사용하고 있다. 하지만 디지털기술이 적 용되면서 치과 진료에서도 기존의 방법을 대체하는 디 지털화된 임상방법이 개발되어 사용되고 있다. 이제 치 아삭제를 제외한 모든 과정, 즉 인상, 모델제작, 보철물 제작에 이르기 까지 모두 컴퓨터와 기계가 담당할 수 있 게 되었다. 이러한 것을 가능하게 하는 가장 중요한 작

업 중 하나가 바로 구강 내의 모습을 3차원적으로 재구 성하여 디지털화 하는 것이다. $\mathrm{CAD} / \mathrm{CAM}$ 시스템의 3 가지 성분 (1) data capture component (digitizers), (2) design component (CAD software), (3) manufacturing component $(\mathrm{CAM})$ 중에서 가장 기본이 되고 뒤의 과정에 상당한 영향을 끼치는 성분은 data capture component, 즉 구강 스캐너이다. 본 종설은 현재 시판중 인 4가지 종류 $\left(\right.$ CEREC $^{\circledR}$, iTero $^{\circledR}$, LAVA C.O.S. ${ }^{\circledR}$, Trios $\left.^{\circledR}\right)$ 의 구내 스캐너 각각의 구동원리와 정확성에 관하여 알 아보았고, 현재 구강 스캐너가 치과 영역에서 임상적으 로 적용되고 있는 분야와 그 분야에서의 적용 정도를 분 석하는데 목적이 있다. 


\section{1. 구강 스캐너의 작동 원리와 각 스캐너의 특성}

\section{(1) 삼각법 (triangulation technique)}

삼각법이란 물체의 형태에 대한 3 차원 데이터를 모아 3 차원 모델을 만드는데 사용되는 비접촉성 기술 중 하 나이다. ${ }^{1}$ 수동적 삼각법과 능동적 삼각법이 있고 모두 사용된다. 먼저 능동적 삼각법은 빛을 직접 방출하여 물 체의 표면에 투영하고 그 반사된 빛을 다시 수집하여 목 표 물체의 위치를 계산해 낸다. 반면 수동적 삼각법에서 는 스캐너에서 직접 빛을 방출하지 않고 반사된 주위의 빛을 탐지해 낸다.

수동적(passive) 삼각법은 다른 말로 수동적 스테레오 비전이라고 부르며 사진 측량 알고리즘을 사용한다. ${ }^{2}$ 이 기술은 위치와 각도를 이미 알고 있는 두 개의 카메라가 두 개의 입체 이미지를 얻는 것을 기초로 한다. 3 차원의 한 점을 두 카메라로부터 얻은 영상정보에서 카메라의 위치와 이를 보는 영상점의 두 벡터는 공통평면상에 존 재한다는 것이 등극선 기하인데, 등극선의 일치하는 점 을 통해 앞서 얻은 두 개의 입체 이미지에 일치하는 물 체의 위치를 알아내는 것이다.

수동적 삼각법은 매우 높은 정확성을 제공하지만 물
체가 높은 대조도를 가지고 있어야 하고 모서리가 뚜렷 하게 형성되어 있어야 한다. 카메라를 3개 사용하면 더 욱 더 정확해 질 수 있다. ${ }^{3}$ 목표물이 아닌 것들은 전혀 측 정되지 않으며 조절된 빛을 사용하지 않을 경우에는 주 위의 빛이 물체의 상을 올바르게 얻어내는 능력에 매우 영향을 준다. 이 방법의 장점은 구성 성분이 몇 개 없고 매우 싸며 작동 원리 또한 우리의 눈과 같아서 간단하다 는 것이다. ${ }^{4} \mathrm{Fig}$. 1 과 같이, 능동적(active) 삼각법은 레이 저에 의해 생성된 빛 광선이 거울에 반사되어 원하는 물 체(Object)로 비추게 된다. 이 기술은 카메라(Position Detector, Lens)에서 나온 실선과 물체가 만나는 지점인 레이저 도트와 카메라 그리고 레이저가 삼각형을 이루 게 된다. 카메라와 레이저 사이의 거리를 알고 있고 이 것을 기준선 거리(d)라고 부르며 삼각형의 한 변에 해당 한다. 레이저의 각도 또한 알려져 있다 $(\theta) .^{5}$ 카메라 시야 에서 얻을 수 있는 카메라 각도 $(\Phi)$ 를 측정해낸 후 기준 선 거리와 레이저 각도와 함께 3 가지 정보를 가지고 삼 각형의 모양과 크기를 결정할 수 있으며 삼각형의 한 점 인 레이저 도트의 3차원적 위치 $(\mathrm{X}, \mathrm{Y}, \mathrm{Z})$ 를 삼각 계산을 통해 알아낼 수 있다. 대부분의 경우에서는 레이저 도트 한 점만을 사용하지 않고 레이저 광선이나 약속된 레이 저 패턴을 사용하여 물체에 대한 정보를 더 빠르게 얻는 다.

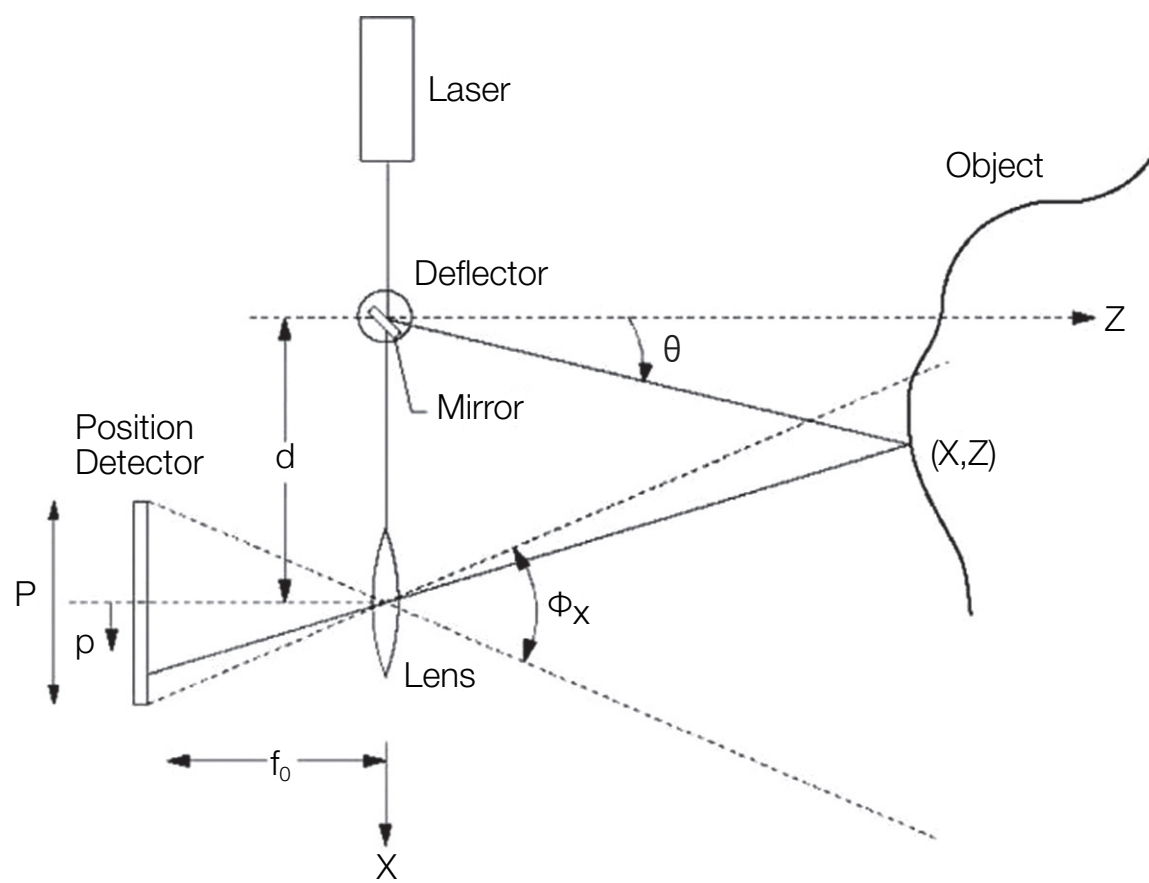

Fig. 1. Active triangulation method. ${ }^{7}$ 
모든 삼각법에 가장 큰 문제는 언제나 목표로 하는 표 면이 레이저와 카메라에 측정되지 않을 가능성이 있다 는 점이다. 이론적인 해결법은 삼각법의 각도를 최대한 줄이는 것이지만 삼각법의 각도를 줄이게 되면 그만큼 정확성이 떨어지게 된다. ${ }^{6}$ 따라서 정확성과 측정되지 않 을 가능성에 대한 바람직한 균형이 고려되어야만 한다.

광삼각 3 차원 이미지 측정 장치는 레이저 빔이 나오는 부분, 카메라 영상 센서 부분, 이송장치, 영상처리 컴퓨 터 부로 이루어져 있다. ${ }^{7}$ 레이저 빔이 이송장치 위에 있 는 목표물에 조사되고 이송장치를 통해 물체를 이동시 키면서 카메라 영상 센서로 영상을 획득하여 컴퓨터로 보내게 되면 컴퓨터가 정보를 수집하여 3차원 이미지를 만들어 내어 화면에 나타나게 된다.

\section{CEREC $^{\circledR}$ by Sirona dental system (Bensheim,}

\section{Germany)}

CEREC은 "Chairside Economical Restoration of Esthetic Ceramics"의 줄임말로 3차원 디지털 스캐너와 밀링머신을 합쳐놓아 한번의 내원으로 도재 블록을 가 공하여 체어 사이드에서 치과적인 수복을 해줄 수 있도 록 만들어진 기계이다. 한번의 내원으로 바로 수복을 할 수 있게 되면 여러 번 내원하지 않아도 된다. 그러므로 임시치아를 만들 필요도 없고 그에 파생되는 여러 문제 점들도 겪지 않아도 된다. CEREC 시스템은 3차원 디 지털화를 하기 위하여 컴퓨터를 이용한 기술을 사용하 게 되는데 디지털 모델로서 정보를 저장하고 인접치와
대합치와의 생체적인 비교를 통해 모양을 정하고 치과 의사로 하여금 모양을 디자인할 수 있게 해준다. 디자인 을 정하고 나면 밀링머신으로 정보를 전송하여 도재나 합성재료 블록을 가지고 단일 크라운을 약 4 분 만에 만 들 수 있도록 설계되었다. 요즘은 인레이, 온레이, 크라 운은 물론 라미네이트 비니어, 심지어 브릿지까지 한번 의 내원으로 완성할 수 있다. ${ }^{8} \mathrm{CEREC}$ 시스템은 앞에 설 명했던 능동적 삼각법의 원리로 이미지를 얻는다. ${ }^{9}$ 먼저 프랩된 치아 주변의 조직을 적당히 당기거나 정리한 후 지혈을 하여 마진이 잘 보이게 해야 한다. 그리고 청색 광 패턴이 무작위적으로 변화하는 기구를 이용하여 빛 을 물체에 조사한다. 그 다음, 각각의 얻은 데이터를 가 지고 광학적 빛의 특성과 이미지 평면 사이의 거리 사이 의 관계를 얻어내어 이미지를 만들게 된다. ${ }^{10}$

Fig. 2 를 보면 빛 근원은 7.1, 7.2, 7.3에 해당하는 조 명 광선을 만들어내며 이것은 목표 물체인 2을 향하여 나아가게 된다. 6 의 이미지 센서가 목표 물체 2 에 반사 된 반사 광선(9.1, 9.2, 9.3)을 받게 되는데 이 때 focusing system(5)을 거치게 되면 반사 광선이 이미지 센서(6)로 잘 모이게 된다. 사실 빛 근원(3)은 빛의 강도 면에서 독 립적으로 조절되는 다양한 구성요소들의 조합(3.1, 3.2, 3.3)으로 이루어져 있다. 따라서 각각의 센서 요소가 감 지하는 빛의 강도는 스캐너의 머리부분과 목표 사물에 해당하는 점 사이의 직접적인 거리를 표시해준다. ${ }^{11}$ 이 때 이 CEREC 시스템에서 중요한 부분인 광삼각법을 사용하기 위해서는 반사하는 표면이 일정해야 한다. 일

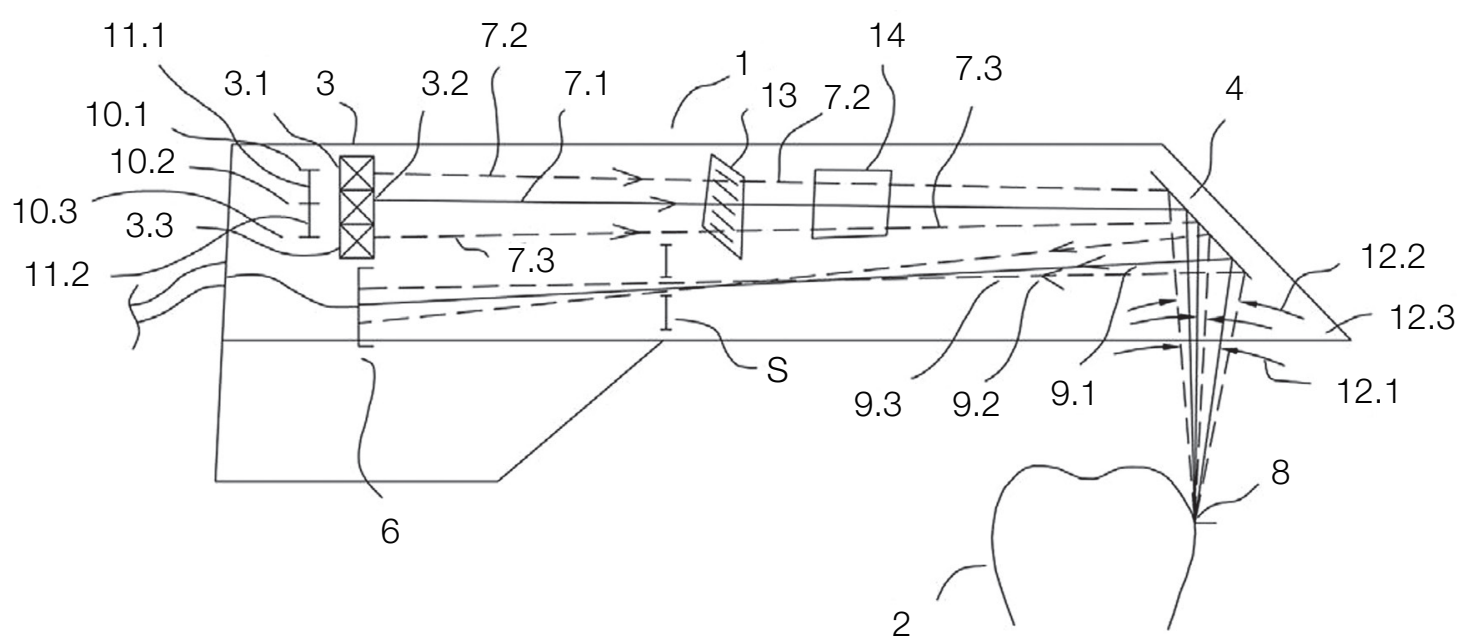

Fig. 2. CEREC scanning principle. ${ }^{12}$ 
정하지 않다면 법랑질, 상아질, 아말감, 레진, 치주조직 등이 모두 다르게 빛을 반사시키게 될 것이다. 따라서 스캔 작업을 시행하기 전에 생체적합적인 TITANIUM DIOXIDE 파우더를 완전하게 덮어서 표면의 반사능을 동일하게 만들어야 한다. ${ }^{9}$

\section{(2) 공초점 레이저 현미경 (confocal laser scanner microscopy)}

공초점 레이저 현미경(confocal laser scanner microscopy, CLSM)은 선택된 깊이에서의 집중된 영상을 얻 을 수 있는 기술로 optical sectioning이라고 알려진 과정 을 거친다. Optical sectioning이란 깊이를 선택하고 그 곳에 초점이 맞지 않는 신호는 광 검출기 앞에 있는 공 초점 조리개로 제거하여 초점면에 맞는 신호만을 모으 는 작업이다. ${ }^{12}$ 이미지들을 각각의 포인트들로부터 모아 컴퓨터로 3 차원 이미지를 만들어낸다. 이 기술을 사용 하게 되면 불투명한 표본의 표면 모습과 투명한 표본의 내부 이미지를 얻을 수 있게 된다. 전통적인 현미경이 빛이 통과하는 만큼 표본을 관찰했다면 공초점 현미경 은 단지 한 번에 한 깊이의 이미지들을 볼 수 있으며 그 깊이와 초점을 조절할 수 있다.

공초점 현미경의 원리는 Marvin Minsky가 1961년 에 특허를 냈지만 레이저를 발전시키고 지금의 형태를 갖는 CLSM을 만드는 데 까지는 30년정도가 걸렸다. CLSM 기술에서 레이저 광선은 조리개를 지나게 되고 이것은 대물렌즈를 지나면서 작은 초점의 용적을 갖도 록 모이게 되며, 우리가 원하는 물체의 내부나 표면에 위 치하게 된다. 흩뿌려지고 반사된 레이저 빛은 다시 대물 렌즈를 지나게 되고 그 빛 중 일부분은 빔 분리기에 의 해 탐지 장치로 보내지게 된다. 이 장치는 형광성 공초점 현미경에서 사용될 때는 필터를 가지고 있는데 이 필터 는 선택적으로 형광성 파장의 빛은 통과시키고 원래 방 출된 파장의 빛은 차단시킨다. 핀 홀을 지나고 난 후 빛 의 세기는 영상 탐지 기구에 의해 탐지되어서 빛 신호를 전기 신호로 바꾸어 컴퓨터가 이를 녹화하게 한다.

제한된 검출 조리개는 초점에서 오지 않은 빛은 다 차 단해버리고, 돌아오는 빛의 대부분은 핀 홀에 의해 차단 되어서 초점에 맞지 않는 빛은 다 억제된다. 그 결과로 전통적인 형광 현미경 기술에서 얻은 이미지보다 더 세 밀한 이미지를 얻을 수 있으며 샘플에서 다양한 깊이에 위치하는 면들의 이미지를 얻을 수 있게 된다. ${ }^{13}$
조명을 받은 물체에서 나온 빛을 탐지하여 얻은 결과 이미지는 하나의 픽셀을 이루게 된다. 이미지 픽셀은 탐 지된 빛의 상대적 강도와 일치하게 된다. 하나나 그 이 상의 보조로 조절되는 진동 거울을 사용하여 수평면에 서 빛의 광선은 샘플을 따라 스캔하게 된다. ${ }^{12}$

스캔을 느리게 할수록 노이즈보다 신호가 더 많이 잡 히며, 더 나은 대조도와 더 높은 해상도를 가지게 된다. 현미경 단이나 대물렌즈를 올리고 내려서 서로 다른 초 점면으로부터의 정보를 얻을 수 있게 된다. 컴퓨터는 이 연속적인 초점면으로부터 얻은 2차원 정보를 결합하여 3 차원 이미지로 생성하게 된다. ${ }^{12}$

\section{(1) iTero ${ }^{\circledR}$ by CADENT LTD (Tel Aviv, Israel)}

Cadent iTero 디지털 인상 시스템은 2007년 초에 시장 에 나왔다. iTero 시스템은 앞서 설명한 평행하는 공초 점 영상기술을 사용한다. ${ }^{13}$ Fig. 3 을 보면 적색 레이저광 선 세트(38)를 초점 광학(42)에 통과시켜 치아에 조사한 다. 이 초점 광학은 모터(72)에 의해 위치가 조절되며 하 나나 그 이상의 초점면을 정해준다. 치아에 조사된 광선 은 구조물에 점을 만들고, 반사된 빛의 강도는 초점면의 다양한 위치에서 측정된다. 치아의 3 차원 이미지는 반 사된 빛의 최대 강도를 통해 알아낸 점의 위치를 기초로 하여 만들어진다. ${ }^{14}$ 이 기술로 iTero는 구강 내 모든 구조 물의 이미지를 만들어낼 수 있으며 이 때 치아에는 어떤 코팅도 하지 않아도 된다. ${ }^{15}$ 전체 구조의 3 차원 이미지는 그 치아 주변에서 얻은 표면의 형상을 모아 만들게 된 다. ${ }^{16}$ 파우더를 코팅하지 않아도 된다는 큰 장점이 있다. 하지만 색이 있는 이미지를 얻기 위해서 추가적으로 스 캐너의 머리부분에 색상환을 달아야 하므로 다른 스캐 너들보다 스캐너의 머리부분이 크다는 단점이 있다. ${ }^{8}$

이 시스템에서는 3 차원 치아 구조의 2 차원 색 이미 지 역시, 구조를 알려고 할 때와 마찬가지로 같은 각도 와 방향을 사용한다. 그 결과 각각의 2차원 색 이미지의 $\mathrm{X}-\mathrm{Y}$ 좌표는 3차원 스캔의 X-Y좌표와 일치하는 점을 갖 게 된다. 색 이미지는 적색, 녹색, 청색의 보색을 사용하 여 얻어지며 각각의 단색들이 합쳐져서 여러 가지 색을 갖는 이미지를 만들게 된다. ${ }^{17}$ 세가지 색 광선은 모두 같 은 백색광에서 얻어지며 이 색 필터는 회전이 가능한 디 스크에 한 부분을 차지하며 모터와 연결되어 있다. 실제 인상을 뜨기 위해서는 프랩된 치아를 다섯 번 스캔한다. 교합면, 설측, 협측 그리고 인접치아의 치간 접촉점을 차례로 스캔하게 되며 약 15 - 20초 정도 시간이 소요된 


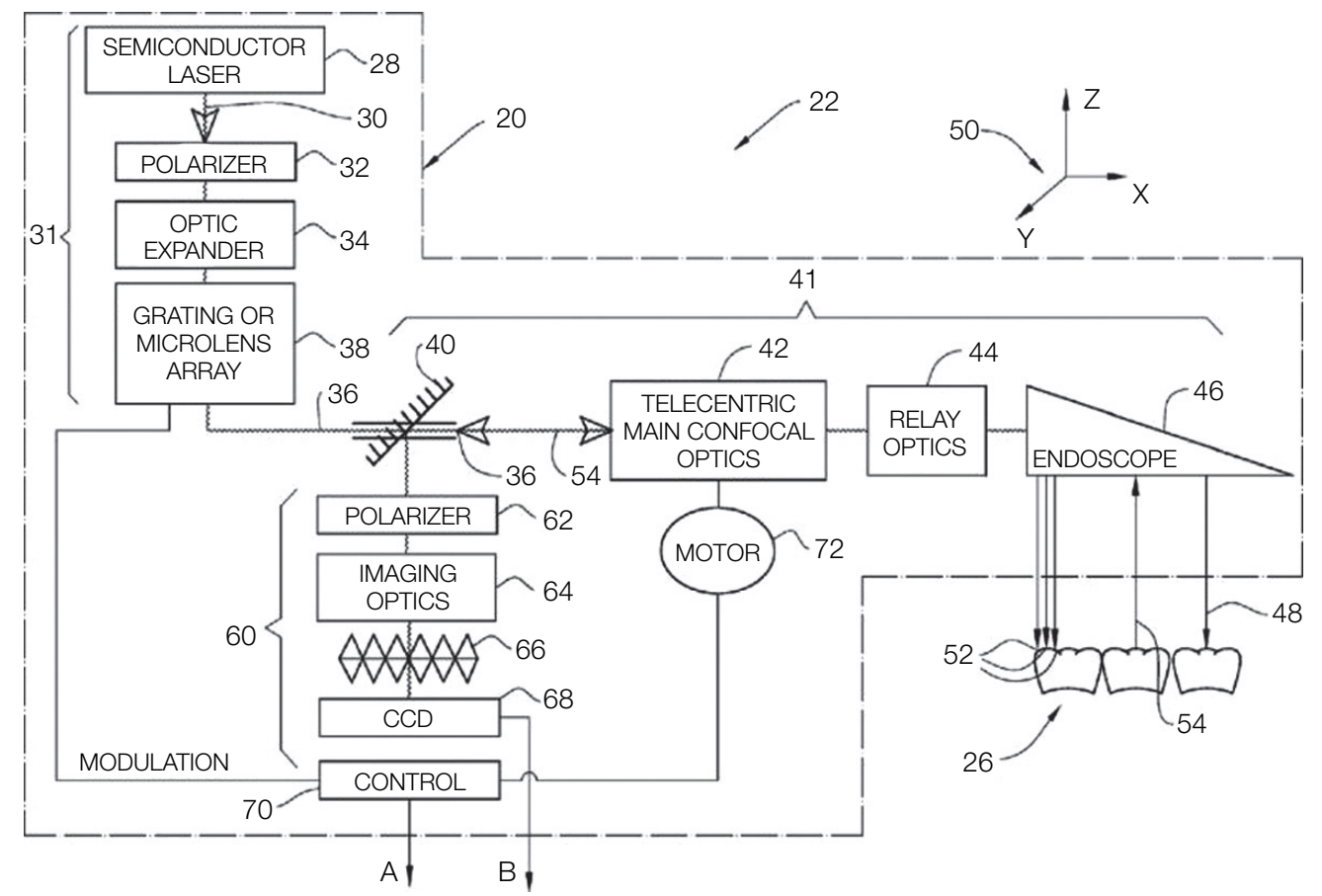

Fig. 3. iTero system. ${ }^{16}$

다. ${ }^{8}$ 그리고 남은 치아를 45 도 각도로 협측과 설측으로 스캔하여 4 분의 1 악이나 대합치 반악을 스캔하게 된다. 이러한 스캔 과정이 끝난 후 환자의 치아를 중심 교합으 로 위치시킨 후 스캔한다. 이 모든 과정을 끝내는 데 약 3 분 정도가 소요된다. ${ }^{18}$

\section{(2) TRIOS $^{\circledR}$ by 3 shape A/S (Copenhagen, Denmark)}

2010년 12월, 3shape 사에서 TRIOS를 시장에 출시했 다. TRIOS는 iTero와 마찬가지로 공초점 현미경의 원 리를 사용하며 빠른 스캔 속도를 가지고 있다. ${ }^{19}$ 빛 진동 을 물체에 일으킬 수 있게 하는 조명 방식을 가지고 있 다. 그 방식 속에서 진동은 공간적이며 다양한 시간대를 가지고 있다. 이 시스템은 물체와 스캐너 사이의 공간적 인 관계는 그대로 두면서 초점면 위치의 범위에 따라 그 방식의 초점면의 다양성을 생성할 수 있는 능력이 있다. 다시 말해 스캐너를 움직이지 않고도 진동을 일으키는 방식 덕분에 다양한 초점면을 생성할 수 있다는 것이다. 또 다양한 시간대를 가지는 진동이 적용될 때 한번의 스 캔으로 초점면의 서로 다른 위치들과 서로 다른 거리에 있는 2 차원 이미지를 얻을 수 있다. 하나의 초점면은 스
캔된 표면에 어떤 픽셀의 위치와 일치할 때 그 패턴은 표면의 한 점에 초점이 맞게 조사되고 높은 대조도를 가 지기 때문에 픽셀 값의 큰 진폭의 상승을 보이게 된다. ${ }^{19}$ 각각의 픽셀이 초점이 맞을 수 있는 초점면을 맞출 수 있는 특정한 설정을 확인하는 것이 가능하다. 그러므로 초점면의 위치에 따른 대조도 정보를 3차원 표면 정보 로 바꾸는 것이 가능하다. 스캔된 물체의 3 차원은 카메 라의 센서 세트 $(180,181)$ 에 속한 각각의 센서에 의해 측 정된 정점과 일치하는 면을 찾는 것으로 결정 된다(Fig. 4). ${ }^{20}$

TRIOS의 가장 중요한 특징은 물체를 스캔할 때 스캐 너를 움직이지 않고 다양한 초점면을 얻을 수 있다는 점 이다. 초점면은 미리 설정된 진동수를 가진 주기적인 방 식으로 연속적으로 얻어져야 한다. 그리고 패턴을 만들 어 내는 수단(130), 카메라(180), 광학 시스템(150)은 서 로 긴밀하게 연결되어 스캔작업을 해야 한다. ${ }^{20}$ 더 나아 가 3 차원 표면을 얻어내는 시간은 probe와 치아 사이 의 상대적인 움직임의 영향을 줄이기 위해서 매우 작아 져야 한다. TRIOS는 스캔되는 물체의 공간에서 볼 때 telecentricity의 특성을 가지고 있고 이러한 특성과 확대 능이 유지되면서 초점면을 변화시킬 수 있다. 


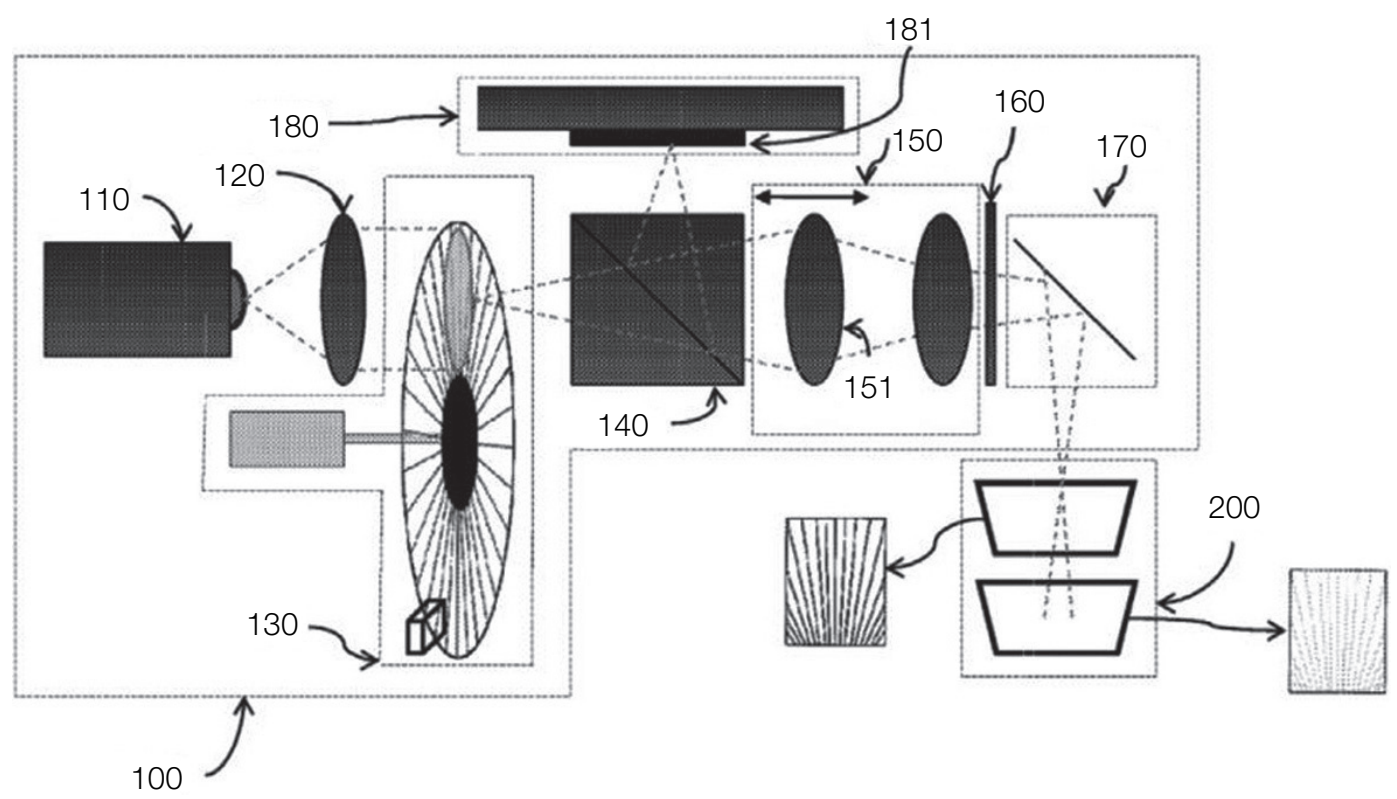

Fig. 4. Trios scanning system. ${ }^{22}$

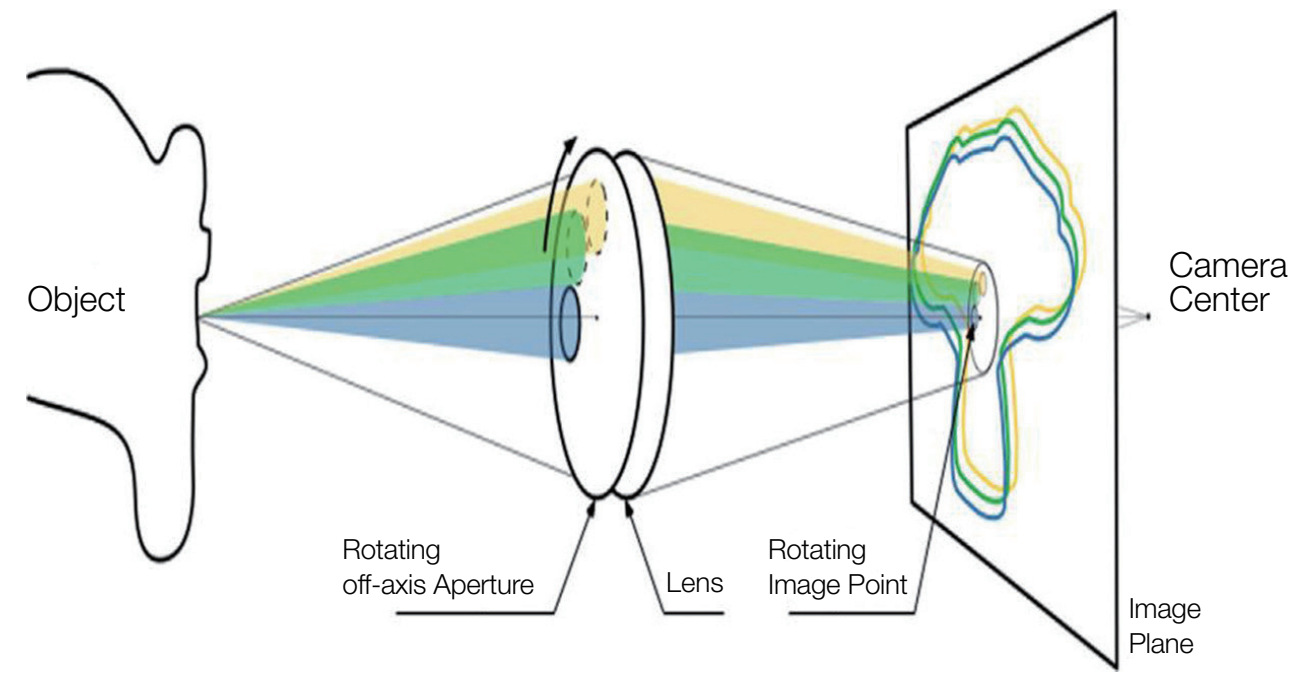

Fig. 5. Active wavefront sampling principle. ${ }^{23}$

(3) 활성 파면 샘플링 (active wavefront sampling and devices)

활성 파면 샘플링(AWS)은 3차원 이미지를 만드는 기 술로 하나의 카메라와 활성 파면 샘플링의 모듈만을 사 용한다. Fig. 5 처럼, 활성 파면 샘플링 모듈의 가장 단순 한 모습은 측면 조리개이며 광축을 주위로 원을 이루며 움직이게 된다. 이러한 움직임은 이미지 평면에 있는 원 에 목표지점의 회전을 생산한다. 목표지점의 깊이에 대 한 정보는 각각의 포인트에서 만들어지고 원을 이루고
있는 포인트 패턴들의 반지름으로부터 얻을 수 있게 되 며, 이러한 것은 회전 하는 활성 파면 샘플링 모듈에 의 해 생성되고 있다. 따라서 활성 파면 샘플링 이미지는 디지털 카메라 하나를 가지고 어떤 시스템이든지 다 3 차원으로 작용할 수 있게 할 능력이 있다. ${ }^{21}$ 그러므로 여 러 개의 카메라로 3 차원 기하를 얻으려고 노력할 필요 가 없어진다. 명백하게 활성 파면 샘플링 시스템의 가장 중요한 특징은 바로 깊이 정보를 얻기 위해서 단 하나의 광학로만 있으면 된다는 것이다. 


\section{Lava Chairside Oral Scanner by 3M ESPE}

\section{(St Paul, MN, USA)}

Lava Chairside Oral Scanner (C.O.S.)는 2006년 10월 $3 \mathrm{M} \mathrm{ESPE}$ 사에서 처음으로 만들어 졌으며 공식적으로 출시 된 것은 2008년 2월이다. Lava C.O.S. 시스템은 하 나의 모바일 카트에 CPU, 터치 스크린 디스플레이, 스 캐닝 기구로 구성되어 있다. ${ }^{22}$

Lava C.O.S. 카메라는 매우 복잡한 광학 시스템으로 이루어져 있는데 22 개의 렌즈 시스템과 192 개의 파란 LED cell로 구성되어 있다. 그리고 구강 스캐너는 13.2 $\mathrm{mm}$ 의 폭과 $390 \mathrm{~g}$ 의 무게가 나간다. ${ }^{23}$ Lava C.O.S.는 3차 원 데이터를 앞서 말한 활성 파면 샘플링의 원리를 이용 하여 대상에 빛을 조사하여 얻어낸다고 알려져 있다. 이 러한 스캐닝 방법을 $3 \mathrm{M} \mathrm{ESPE}$ 사에서는 '3D-in Motion technology' 라고 명명하고 있다. ${ }^{22}$ 이 스캐닝 시스템은 활성화된 3차원 이미지 시스템을 제공하는데, 이것은 회전하는 측면 조리개를 포함하고 있다. 이 회전하는 조 리개는 광원로에 위치하거나 광학 장치의 영상로에 위 치하고 있다. Lava C.O.S.는 측면 조리개가 영상로에 위 치하는 3 차원 이미지 시스템의 원리를 보여주고 있다. ${ }^{24}$
광학 장치는 대상을 보는 렌즈들을 의미하며 회전체는 측면 조리개의 요소로 회전하는 요소이다. 화상처리 장 치는 화상처리 과정을 수행하는 하드웨어를 뜻한다. 화 상처리 장치와 회전체는 서로 조절을 위해 피드백 과정 을 가진다. Fig. 6는 현재 Lava C.O.S.를 구동하는 이론 인 활성 파면 샘플링을 보여주는 것으로써, 광파면 샘플 링을 통해 초점 밖의 면을 측정하는 개념과 물체의 포 인트를 조합하는 것을 보여준다. 이 시스템은 크게 렌즈 (140), 회전하는 조리개 요소(160), 상평면(18 A)으로 이 루어져 있다. R은 측면 pupil을 따라 원 모양으로 회전했 을 때 그 직경을 말하며 d는 상평면에 생긴 초점 밖의 포 인트의 이미지를 따라 그은 원의 직경이다. ${ }^{24}$ 하나의 조 리개는 다른 물체 부분으로부터의 이미지들의 겹침을 피할 수 있다. 따라서 회전하는 조리개는 여러 조리개 위치에서 얻어진 이미지를 얻을 수 있게 하며 이것은 다 른 시점에 있는 여러 개의 카메라에 의해 해석될 수 있 다. 그러한 다양한 시점은 측정 민감도를 증가 시킬 수 있다. 활성화로 조절된 조리개의 운동은 이미지 불균형 을 조절하여 이동 탐지의 정확성을 증가 시킬 수 있게 한다.

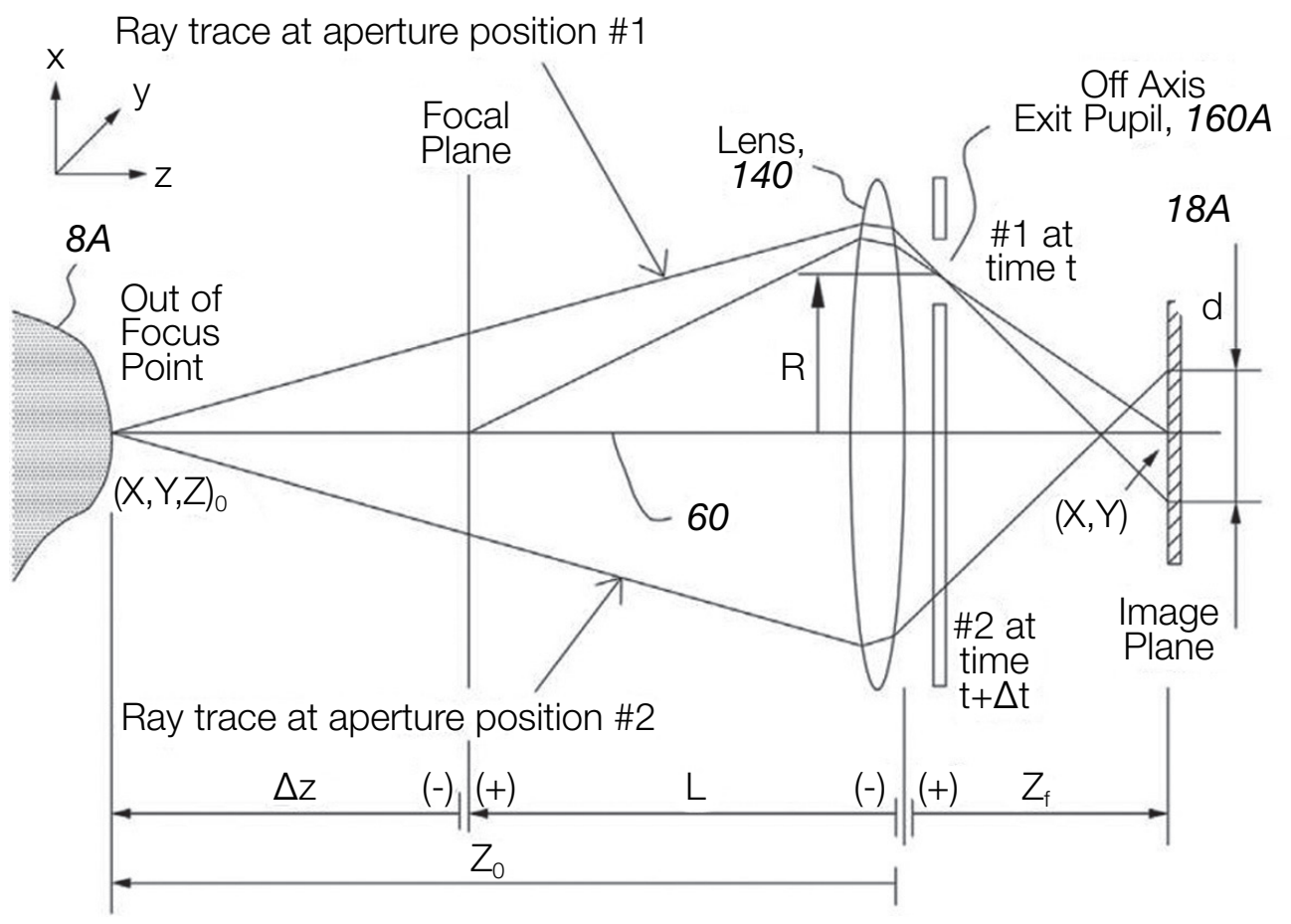

Fig. 6. Lava C.O.S.의 Active wavefront sampling principle. ${ }^{27}$ 
이미지의 가공을 위해 부분화된 상호 상관을 적용하 여 프레임 사이에 이미지 불균형을 줄여나갈 수 있다. 자기 상관보다 상호 상관을 사용하는 것은 장점이 많은 데, 자기 상관의 주요 문제점을 해결하여 소음 수준을 낮출 수 있고, 초점을 보다 잘 잡을 수 있으며 방향적으 로 애매한 부분을 없앨 수 있다. ${ }^{25}$ 이러한 장점들은 노이 즈보다 신호의 비율을 높이고 더 높은 공간적, 심도적 인 해상도를 가지게 하고 불확실하게 실행할 확률을 줄 인다. 조리개의 움직임은 $\mathrm{CCD}$ 요소에 다른 조리개 위 치에 있는 하나의 노출된 이미지를 저장할 수 있게 해준 다. 부분화된 자기 상관의 작용으로 상평면 $(18 \mathrm{~A})$ 에 최 소 두 개 이상의 이미지가 기록된다. ${ }^{24}$

\section{2. 구강 스캐너의 적용 분야와 그 분야에서의 정확성 기술}

현재 구강 스캐너가 치과 영역에서 적용 되고 있는 분 야와 그 분야에서의 적용 정도를 분석하였다.

\section{(1) 수복}

Pubmed와 구글 스칼라에 검색어: '디지털 인상 지르 코니아, '디지털 인상 전부도재관' 의 검색어로 최근 5년 간 논문을 검색 한 후, 관련성이 있는 데이터만을 추출 하여 기술하였다.

(1) 구강 스캐너의 정확성, 기존의 전통 방식과의 비교 $\mathrm{An}$ 등 $^{26}$ 은 세라믹 크라운 제작을 위하여 준비한 하나 의 상악 중절치를 이용하여 30 개의 동일한 모형을 제작 하였다. 10 개씩 군을 나누었으며 각각은 (1) 폴리비닐 실 록산 인상재로 stone die를 만들어서 제작, (2) iTero 시 스템으로 폴리우레탄 die를 만들어서 제작, (3) iTero 시 스템으로 die를 만들지 않고 제작 (스테레오리소그라피 파일) 한 다음 변연의 차이를 관찰하였다. 그 결과, (1) $92.67 \mu \mathrm{m}$ (2) $103.05 \mu \mathrm{m}$ (3) $103.55 \mu \mathrm{m}$ 으로 측정되었다. 결론적으로, 전통적인 방법이 iTero 시스템으로 인상을 떠서 제작 한 것보다 더 정확하였으며 그 결과는 유의미 한 차이를 보였다. 하지만 어떤 절대적인 임상적으로 받 아들일 수 있는 변연의 차이의 양이 정해져 있지는 않으 며 세 방법 모두 임상적으로 받아들일 수 있었다.

$\mathrm{Ng}$ 등 $^{27}$ 에서는 17 번 치아의 세라믹 크라운 30 개를 대 상으로 15 개씩 나누어서 실험하였으며 각각은 (1) 전통
적 인상방법(폴리비닐실록산 인상재)로 인상 뜬 다음 제 작, (2) 디지털 인상방법: Lava C.O.S.로 인상 뜬 다음 제 작하였다. 그 다음 완성된 30개를 근심, 원심, 협측, 구개 측, 근심협측, 근심설측, 원심협측, 원심설측, 즉 총 8 면 을 보아서 240 면의 변연의 차이를 조사하였다. 그 결과, (1) $74 \mu \mathrm{m}$, (2) $48 \mu \mathrm{m}$ 으로 조사되었다. 즉 전통적인 인상 방법이 디지털 인상방법 보다 부정확했다. 하지만 두 방 법 모두 임상적으로 양호했다.

Lee 등에서는 ${ }^{28} 3$ shape $\mathrm{A} / \mathrm{S}$ 을 사용한 실험으로 각각 은 (1) 러버인상재를 이용하여 만든 working model을 스 캔하여 만든 모형, (2) 스캐너를 이용하여 디지털 인상 체득 후 만든 디지털 모형에서 변연의 차이를 측정하였 다. 그 결과 (1) $28.9 \mu \mathrm{m},(2) 117.7 \mu \mathrm{m}$ 으로 조사되었다. 즉 working model로 얻은 데이터가 디지털 인상방법의 데이터보다 정확했고 유의미한 차이를 보였으나 두 개 모두 임상적으로 받아들일 수 있었다.

Keul 등 ${ }^{29}$ 은 iTero 스캐너를 이용하여 4-unit 가공의치 의 변연 적합도를 분석하였다. 12 개는 스캔하였고 12 개 는 전통적인 인상방법을 사용하였다. 그리고 이것을 가 지고 각각 금속와 지르코니아를 사용하여 다음과 같이 모형을 만들었다: (1) 전통적인 인상 방법을 사용하여 만 든 금속, (2) 디지털 인상 방법을 사용하여 만든 금속, (3) 전통적인 인상 방법을 사용하여 만든 지르코니아, (4) 디 지털 인상 방법을 사용하여 만든 지르코니아였다. 변연 의 적합도를 측정한 결과 (1) $90.64 \mu \mathrm{m}$ (2) $56.90 \mu \mathrm{m}$ (3) $141.08 \mu \mathrm{m}$ (4) $127.23 \mu \mathrm{m}$ 로 조사되었으며 디지털 인상 방법이 전통적인 방식보다 더 정확하였다. 또한 금속으 로 만든 것이 지르코니아보다 더 정확하였으나, 모든 인 상방법과 사용한 재료는 다 임상적으로 받아들일 수 있 을 정도의 정확성을 보여 주었다.

Syrek 등 ${ }^{30}$ 은 (1) Lava C.O.S.와 (2) 전통적인 인상 방법 (실리콘)으로 인상을 뜬 전부 도재관 변연 적합도를 비 교하였다. 그 결과, (1) $49 \mu \mathrm{m}$, (2) $71 \mu \mathrm{m}$ 로 측정되었다. 즉, 실리콘을 사용한 기존의 인상방법보다 디지털 인상 방법이 유의미하게 변연의 적합도가 더 좋았다. 하지만 두 방법 모두 임상적으로 받아들일 수 있다.

Silva 등 $^{31}$ 은 (1) 전통적인 인상방법 12 개(폴리에스테 르)와 (2) Lava C.O.S. 마스터 모델 12개로 4개의 지르코 니아 고정성 치아 보철물을 만들고 변연의 적합도와 치 내의 적합도를 측정하여 비교 하였다. 그 결과 변연의 적합도는 (1) $65.33 \mu \mathrm{m}$ (2) $63.96 \mu \mathrm{m}$, 치내의 적합도는 (1) $65.94 \mu \mathrm{m}$ (2) $58.46 \mu \mathrm{m}$ 였다. 따라서 유의미하게 디 
지털 인상방법을 한 것이 더 정확했지만 둘 다 임상적으 로 문제가 없었다.

이상의 연구 결과를 종합해보면, An 등 ${ }^{26}$ 과 Lee 등 ${ }^{28}$ 은 기존의 방식이 더 정확하게 나온 반면, 나머지 연구들에 서는 구강 스캐너를 사용한 디지털 인상 방법이 더 정확 한 보철물을 만들었다. 그러나, 실험에서 측정한 측정값 들은 모두 달랐음에도 불구하고 모두 임상적으로 허용 가능한 범위 내에 있었다.

\section{(2) 재료에 따른 차이}

Keul 등 ${ }^{29}$ 에서는 지르코니아와 금속 간의 차이를 볼 수 있었다. 같은 재료의 인상재를 사용하더라도(디지 털 인상 방법, 전통적인 인상 방법) 금속이 지르코니아 보다 정확한 변연의 적합도를 보이는 결과가 있었다. 그리고 Baig 등 ${ }^{32}$ 은 (1) Cercon Y-TZP (yttria-stabilized tetragonal zirconia polycrystals)와 (2) IPS Empress II (3) 전부 금속관의 변연의 차이를 비교하였다. 그 결과 (1) $66.4 \mu \mathrm{m}$, (2) $36.6 \mu \mathrm{m}$, (3) $37.1 \mu \mathrm{m}$ 의 차이를 보였다. 지르코니아가 조금 더 부정확하기는 했지만 임상적으로 적용하기에는 문제가 없다는 결론을 지을 수 있었다. 금 관과 비교하였을 때는, Wang 등 ${ }^{33}$ 는 35 개 구치부 CAD/ $\mathrm{CAM}$ 지르코니아를 dental wings s50로 제작 후, 30 개의 금관과 비교하여 2년간 확인하였다. 그 결과, 균열 여부, 심미성, 접촉 마모에 관해 문제가 없었으나 대합치만 조 금 마모되어 있었다. 즉, 지르코니아로 수복해도 금관 과 같이 2년은 파절도 없고 접촉 마모의 문제도 없지만, 대합치 마모의 문제가 있기 때문에 상악, 하악 양쪽을 다하는 것이 낫다는 결론을 내렸다. Scotti 등 ${ }^{34}$ 은 Lava C.O.S.로 제작한 구치부와 전치부에 있는 37 개의 단일 지르코니아 도재관을 대상으로, 변연의 차이, mid-axial 부위, axio-occlusal 부위, 중심 교합 부위에서 모형과 금 관 내부 사이의 거리를 측정하였다. 그 결과 각각 48.65 $\mu \mathrm{m}, 112,25 \mu \mathrm{m}, 137.81 \mu \mathrm{m}, 157.25 \mu \mathrm{m}$ 였으며, 구치부와 전치부 간에 유의미한 차이를 보이지 않았다. 즉, Lava C.O.S를 사용하면 구치부나 전치부나 상관없이 모두 다 임상적으로 받아들일 수 있는 범위 내로 만들어진다는 것을 의미한다. 또 비슷한 연구로 Tamim 등 ${ }^{35}$ 에 따르면 50 명의 디지털 인상 방법으로 제작한 금속 도재관에서 모형과 금관 내부 사이의 거리를 조사해본 결과, 변연의 적합도: $46 \mu \mathrm{m}$, mid-axial 부위: $94 \mu \mathrm{m}$, 중심 교합 부위: $185 \mu \mathrm{m}$ 을 보였다. 이 역시 모두 임상적으로 받아들일 수 있는 범위 내에 있었다.

\section{(3)스캐너에 따른 차이}

Brawek 등 ${ }^{36}$ 은 (1) Lava C.O.S.와 (2) CEREC AC와 의 비교하기 위해 14 개의 지르코니아로 변연의 차이, mid-axial, axio-occlusal, 중심 교합 부위에서 모형과 도 재관 내부 사이의 거리를 측정하였다. 그 결과, 변연의 차이는 (1) $51 \mu \mathrm{m}$ (2) $83 \mu \mathrm{m}$ 였고, mid-axial 부위는 (1) $130 \mu \mathrm{m},(2) 128 \mu \mathrm{m}$ 로 기록되었으며, axio-occlusal 부 위는 (1) $178 \mu \mathrm{m}$ (2) $230 \mu \mathrm{m}$ 을 보였고, 중심 교합은 (1) $181 \mu \mathrm{m}$ (2) $297 \mu \mathrm{m}$ 로 측정되었다. 즉, Lava C.O.S.가 CEREC AC보다 더 적합함을 보여주며 유의미한 차이 를 보였으나 두 방법 모두 임상적으로 만족스러운 결과 를 보였다. Seelbach 등 ${ }^{37}$ 은 (1) Lava C.O.S., (2) CEREC, (3) iTero, (4) 전통적인 인상 방법(실리콘)으로 전부 도 재관 제작 후 변연의 적합도와 치내의 적합도를 각 각 측정하였다. 변연의 적합도는 (1) $48 \mu \mathrm{m}$ (2) $30 \mu \mathrm{m}$ (3) $41 \mu \mathrm{m}$ (4) $44 \mu \mathrm{m}$ 였고, 치내의 적합도는 (1) $29 \mu \mathrm{m}$ (2) $88 \mu \mathrm{m}$ (3) $50 \mu \mathrm{m}$ (4) $49 \mu \mathrm{m}$ 였다. 즉 변연의 적합도 는 CEREC이 가장 정확하였고, 치내의 적합도는 Lava C.O.S.가 제일 정확하였다. 3 가지 구강 스캐너와 전통적 인 인상 방법 모두 고정된 보철 수복에 적합하였다.

\section{(4) Margin preparation에 대한 차이}

$\operatorname{Re}$ 등 $^{38}$ 은 인공 치아 20 개를 chamfer finish line 과 rounded shoulder finish line으로 준비한 후 Lava C.O.S.로 스캔하였다. 그 결과 둘은 전혀 유의미한 차 이가 없었다. Souza 등 ${ }^{39}$ 은 (1) tilted chamfer, (2) large chamfer, (3) rounded shoulder finish line으로 준비한 후 변연의 적합도과 치내의 적합도를 측정하였다. 그 결과, 변연의 적합도는 (1) $99.92 \mu \mathrm{m}$, (2) $64.71 \mu \mathrm{m}$, (3) $28.24 \mu \mathrm{m}$ 이었고, 치내의 적합도는 (1) $216.26 \mu \mathrm{m}$, (2) $183.01 \mu \mathrm{m}$, (3) $219.12 \mu \mathrm{m}$ 로 측정되었다. 즉, 변연의 적 합도의 정확성은 rounded shoulder가 높았고, 치내의 적합도의 정확성은 large chamfer가 높았다. Renne 등 ${ }^{40}$ 은 Preparation의 정확성에 따른 변연의 차이을 조사하 였다. 62 명의 임상가가 1 시간씩 책보고 프랩을 하여서 (1) Ideal preparations (25명) (2) Considered fair (34명) (3) Categorized as poor (15명)로 책에 설명된 올바른 preparation에 대한 지침을 읽고 판단을 내렸다. 그 후 변연의 차이를 조사한 결과 (1) $38.5 \mu \mathrm{m}$ (2) $58.3 \mu \mathrm{m}$ (3) $90.1 \mu \mathrm{m}$ 으로 측정되었다. 즉, preparation이 정확할수록 디지털 인상방법이 잘 이루어지고 최종 보철물의 변연 의 차이가 더 줄어드는 것을 알 수 있었다. 


\section{(2) 임플란트}

Pubmed와 구글 스칼라에 검색어: '디지털 인상 임플 란트' 의 검색어로 최근 5 년간 논문을 검색 한 후, 관련 성이 있는 데이터만을 추출하여 기술하였다.

\section{(1) 임플란트 인공 치근을 심은 후 인상의 정확성}

Giménez 등 ${ }^{41}$ 은 iTero 스캐너로 작동자의 경험, 식립 각도, 깊이에 따른 스캐닝의 정확도 차이를 알아 보았 다. 그 결과, 작동자의 경험은 별로 상관이 없었고 각도 가 커진다고 해서 디지털 인상 방법의 정확성이 줄어들 지 않았다. 또한 깊이는 깊다고 해서 정확성이 줄어들지 않았다. 다만 스캔하는 구역이 커지면 커질수록 정확성 은 줄어들었다. Abdel-Azim 등 ${ }^{42}$ 은 single unit과 전악 임 플란트 모형에 대해 각각 디지털 인상/기공 방법과 전 통적인 인상/기공 방법을 시행하여 협/설측에서 변연 적합도를 측정, 비교하였다. 단일 임플란트 시 전통적 인 인상/기공 방법은 $24.1 \mu \mathrm{m}$, 디지털 인상/기공 방법 은 $61.43 \mu \mathrm{m}$ 로 기존의 전통 방식이 더 변연의 적합도가 잘 맞았다. 전악 임플란트 모형 시 전통적인 인상/기공 방법은 $135.1 \mu \mathrm{m}$, 디지털 인상/기공 방법은 $63.14 \mu \mathrm{m}$ 로 디지털 인상/기공 방법 결과의 변연의 적합도가 더 높 았다. 하지만 single unit과 전악 임플란트 모형에서 전통 적 방법과 디지털 방법 모두 임상적으로 문제 없을 정도 의 변연의 적합도를 보였다. Papaspyridakos 등 ${ }^{43}$ 은 2000 개가 넘는 논문을 리뷰해서 76 개의 연구 중 41 개는 무치 악, 35 개는 부분 무치악 환자로 나누어서 연구하였는데, 이 중 3 개의 부분 무치악 환자에 대한 논문이 디지털 인 상에 대한 연구였다고 밝혔다. 세 연구 모두 기존의 오 픈 트레이 방식보다 디지털 인상 방식이 덜 정확하다고 보고하였다. Stoetzer 등 ${ }^{44}$ 은 디지털 인상 방식을 응용하 여 임플란트 식립 후 인공 치근의 위치 파악을 시도하였 으며 Cone beam 컴퓨터 단층촬영과 비교하였을 때 정 확도가 떨어지지 않는다고 하였다. 따라서, $\mathrm{x}$-ray를 찍지 않고 임플란트의 위치를 알 수 있는 장점이 있으므로 편 리할 뿐만 아니라, 환자의 방사선 노출량을 줄일 수 있 다고 하였다.

(2) 디지털 인상을 이용한 유도된 임플란트 수술

Nickenig과 Eitner ${ }^{45}$ 는 23개의 임플란트를 수술 표 본으로 사용 후 식립 시 계획했던 것과 실제 식립 위 치를 확인하였는데, 4.2 도 정도 차이가 나고 임플란트 shoulder는 $0.9 \mathrm{~mm}$ 차이, 임플란트 근첨은 $0.6 \mathrm{~mm}$ 정도 차이가 났다. 이 정도 차이는 임상적으로 허용될 만 하 다고 결론지었다. Mandelaris와 Vlk ${ }^{46}$ 과 Stapleton ${ }^{47}$ 은 디 지털 인상을 이용한 임플란트 수술에 대한 케이스를 발 표하였다. CAD/CAM fabricated, 임플란트 유지형 고 정성 치아 보철물로서 디지털 진단 인상을 제작한 후 이 데이터를 cone beam CT와 연계하여 정확한 진단을 내 렸다. 또한, 가상 계획을 통해 정확한 각도와 깊이를 계 산해내고 컴퓨터가 유도하여 수술 견본을 만들어 심은 후, 즉각적인 예비 보철까지 구강 스캐너를 사용하여 진 행하였다. 그 후 과정은 전통적인 보철물 제작 과정을 사용하였으며 보철물에 대한 이상은 없었다.

\section{(3) 가철성 보철물}

가철성 보철물에 대한 디지털 인상에 관련된 논문을 발견하기가 어려웠다. Papaspyridakos 등 ${ }^{43}$ 도 2879 개의 논문을 리뷰하였으나, 무치악 환자에 대한 디지털 인상 의 정확성에 관한 논문은 찾을 수 없다고 밝혔다.

하지만, 최근 발표된 논문 중에서, Ender와 $\mathrm{Meh}^{48}$ 은 전악 인상으로, CEREC의 디지털 인상과 전통방식 의 인상 (비닐실록산 인상재)을 정확성과 정밀성의 관 점에서 비교하였다. 그 결과, 편위의 패턴이 전통 방식 과 디지털 방식이 달랐다. 전통 방식으로 인상채득한 것 은 전치부와 소구치 부분은 편위가 작고 원심단 부분 은 $50 \mu \mathrm{m}$ 로 가장 크고 왜곡이 있었다. 그에 비해 디지털 방식은 제일 심한 부분은 $170 \mu \mathrm{m}$ 차이가 나고, 전체적 인 모델이 시상, 수평축 모두 다 심하게 왜곡되어 있었 다. 하지만 $170 \mu \mathrm{m}$ 의 차이는 임상적으로 받아들이지 못 할 오차는 아니라고 앞선 수많은 논문에서 결론을 내렸 다. Kattadivil 등 ${ }^{49}$ 은 iTero 구강 스캐너를 통해 Kennedy class II에 대한 가철성 국소의치를 완성한 첫 사례 보고 를 하였다. 이에 따르면, 치아와 교합을 28 번 스캔하였 고 레스트 시트, 안내면, 연부 조직과 상악 구개를 25번 스캔하였으며 대합치 또한 28 번 스캔하여 총 81 번의 스 캔을 17 분동안 진행하였으며, Cadent iTero를 가지고 폴 리우레탄 주물을 만들어 가상설계를 해당 소프트웨어인 SensAble (Sensable Technology Inc.'s ${ }^{\circledR}$ )을 통해 진행하 여 레진 패턴을 $3 \mathrm{D}$ 프린팅하였다고 보고하였다. 그 다 음 과정은 모두 전통적인 방법으로 주조하고 제작하였 으며 최종보철물의 적합도는 정확하였고 환자는 불편을 느끼지 않았다고 보고하였다. 


\section{결론}

연구한 구강 스캐너들은 삼각법(triangulation technique), 공초점 레이저 현미경(confocal laser scanner microscopy), 활성 파면 샘플링(active wavefront sampling) 등의 방식을 사용하고 있으며, 이 방법들을 사용하고 있 는 스캐너들인 CEREC, iTero, Lava C.O.S., Trios의 정 확성 또한 모두 실험마다 차이는 있지만, 모두 일정 수 준 이상의 정확성을 보이고 있으며 임상적으로 무리가 없을 정도의 수준에 이르렀다. 일부 실험에서는 디지털 인상이 임상적 기준을 넘었을 뿐만 아니라, 기존 전통방 식으로 인상을 떠서 만든 보철물보다 더 정확하기도 하 였다. 그리고 그 정확성은 디지털 인상 후 만들어지는 보철물의 재료에 따라 상이한 결과를 보였고 인상 시 마 진의 모양이나 정확성에 따라 차이를 보였다. 이들 스캐 너들은 치과 분야에서 간단한 단일 수복부터 교의치, 임 플란트, 고정성 치아 보철물, 가철성 보철물 등의 제작 과정에도 일부 사용되고 있으며, 최종적으로 만들어진 보철물들의 적합도, 안정감, 유지가 임상적으로 문제가 없을 정도의 수준이라고 보고되고 있다. 하지만 아직 디 지털 인상방식에 대한 정확성이나 사례보고 등이 많이 부족하므로, 디지털 인상이 치과 진료에서 더 큰 도움이 되기 위해서는 수많은 추후 연구가 필요하다.

\section{Acknowledgments}

본 연구는 산업통상자원부의 재원으로 산업핵심기술 개발사업의 지원에 의하여 이루어진 것임(10048888).

\section{Orcid}

Young-Jun Lim http://orcid.org/0000-0003-2504-9671

Jung-Suk Han http://orcid.org/0000-0002-9439-1465

Seung-Pyo Lee http://orcid.org/0000-0002-0103-6705

\section{References}

1. Ali P, Behrai T. A reliable 3D laser triangulationbased scanner with a new simple but accurate procedure for finding scanner parameters. J Am Sci 2010;6:80-5.

2. Kostiukova VV, Riakhovski AN, Ukhanov MM. A Comparative Analysis Of Intra-oral 3d digital scan- ners for restorative dentistry. Stomatologiia (Mosk) 2014;93:53-9.

3. Franca JGDM, Gazziro MA, Saito JH. A 3D scanning system based on laser triangulation and variable field of view. IEEE Intl Conf 2005;1:425-8.

4. Wang L, Bo M, Gao J, Ou CS. A Novel double triangulation 3D camera design. IEEE Intl Conf Info 2006:877-82.

5. El-Hakim SF, Beraldin JA, Blais F. Comparative evaluation of the performance of passive and active 3D vision systems. Proc. SPIE 2646, Digital Photogrammetry and Remote Sensing '95, 14 (December 1, 1995); doi:10.1117/12.227862.

6. Lombardo V, Marzulli T, Pappalettere C, Sforza P. A time-of-scan laser triangulation technique for distance measurements. Opt Laser Eng 2003;39:24754.

7. Logozzo S, Zanetti EM, Franceschini G, Kilpelä A, Mäkynen A. Recent advances in dental optics - Part I: 3D intra-oral scanners for restorative dentistry. Opt Laser Eng 2014;54:203-21.

8. Birnbaum NS, Aaronson HB, Stevens C, Cohen B. 3D digital scanners: a high tech approach to more accurate dental impressions. Inside Dent 2009;5:704.

9. Thiel F, Pfeiffer J, Fornoff P. Apparatus and method for optical 3D measurement. US Patent 2011/ 7986415

10. Thiel E, Pfeiffer J, Fornoff P. Apparatus and method for optical 3D measurement. International Publication WO Patent 2008/7986415 B2.

11. Schmidt V. 3D dental camera for recording surface structures of a measuring object by means of triangulation. International Publication WO Patent 2010/012838 A1.

12. Pawley JB. Handbook of biological confocal microscopy. $3^{\text {rd }}$ ed. NewYork; Springer; 2006.

13. Fellers TJ, Davidson MW. Olympus FluoView Resource Center: introduction to confocal microscopy. Available from: http://www.olympusconfocal. com/theory/confocalintro.html (updated 2014 Oct 15).

14. Babayoff N, Glaser-Inbari I. Imaging a three dimensional structure by confocal focusing an array of light beams. International Publication WO Pat- 
ent 2000/08415.

15. Harrison L. Digital impressions competition booming, Available from: http://www.drbicuspid.com/ index.aspx?sec $=$ sup $\&$ sub $=$ rst\&pag $=$ dis $\&$ ItemID $=$ 301650 (updated 2014 Oct 15).

16. Babayoff N, Glaser-Inbari I. Method and apparatus for imaging three-dimensional structure. US Patent 2007/0109559.

17. Babayoff N. Method and apparatus for colour imaging a three dimensional structure. US Patent 2010/0208275 A1.

18. Jacobson B. Taking the headache out of impressions. Dent Today 2007;26:74,76.

19. 3Shape. 3Shape TRIOSs digital impression solution. Available from: http://www.3shapedental.com (updated 2014 Oct 15).

20. Fisker R, Öjelund H, Kjær R, VanDerPoel M, Qazi AA, Hollenbeck KJ. Focus scanning apparatus. International Publication WO Patent 2010/ 145669A1.

21. Heber S. 3d image reconstruction using active wavefront sampling. Available from: http://rvlab. icg.tugraz.at/project_page/project_wavefront/ project_wavefront.htm (updated 2014 Oct 15).

22. Fasbinder DJ. Digital workflow for the Lava C.O.S system. Inside Dent 2009;5.

23. 3M ESPE. Lava ${ }^{\text {TM }}$ ScanSToptical scanning system. Available from: http://solutions.3m.co.za/wps/ portal/3M/en_ZA/3M_ESPE/Dental Manufacturers/Products/DigitalDentistry/Dental Technician/DentalCAD-CAM/DentalScanners (updated 2014 Oct 15).

24. Hart DP, Lammerding J, Rohaly J. 3-D imaging system. US Patent 2004/0155975 A1.

25. Kondon N. Making the switch to the Lava C.O.S. Available from: http://www.benco.com/About/ News/Making_the_Switch_to_the_Lava_C_O_ S_.aspx (updated 2014 Oct 15).

26. An S, Kim S, Choi H, Lee JH, Moon HS. Evaluating the marginal fit of zirconia copings with digital impressions with an intra-oral digital scanner. J Prosthet Dent 2014;112:1171-5.

27. Ng J, Ruse D, Wyatt C. A comparison of the marginal fit of crowns fabricated with digital and conventional methods. J Prosthet Dent 2014;112:555-
60.

28. Lee WS, Kim WC, Kim HY, Kim WT, Kim JH. Evaluation of different approaches for using a laser scanner in digitization of dental impressions. J Adv Prosthodont 2014;6:22-9.

29. Keul C, Stawarczyk B, Erdelt KJ, Beuer F, Edelhoff D, Güth JF. Fit of 4-unit FDPs made of zirconia and CoCr-alloy after chairside and labside digitalization-a laboratory study. Dent Mater 2014;30:4007.

30. Syrek A, Reich G, Ranftl D, Klein C, Cerny B, Brodesser J. Clinical evaluation of all-ceramic crowns fabricated from intra-oral digital impressions based on the principle of active wavefront sampling. J Dent 2010;38:553-9.

31. Almeida e Silva JS, Erdelt K, Edelhoff D, Araújo É, Stimmelmayr M, Vieira LC, Güth JF. Marginal and internal fit of four-unit zirconia fixed dental prostheses based on digital and conventional impression techniques. Clin Oral Investig 2014;18:515-23.

32. Baig MR, Tan KB, Nicholls JI. Evaluation of the marginal fit of a zirconia ceramic computer-aided machined (CAM) crown system. J Prosthet Dent 2010;104:216-27.

33. Wang YG, Xing YX, Sun YC, Zhao YJ, Lü PJ, Wang Y. Preliminary evaluation of clinical effect of computer aided design and computer aided manufacture zirconia crown. Zhonghua Kou Qiang Yi Xue Za Zhi 2013;48:355-8.

34. Scotti R, Cardelli P, Baldissara P, Monaco C. WITHDRAWN: Clinical fitting of CAD/CAM zirconia single crowns generated from digital intraoral impressions based on active wavefront sampling. J Dent 2011 Oct 17. [Epub ahead of print]

35. Tamim H, Skjerven H, Ekfeldt A, Rønold HJ. Clinical evaluation of CAD/CAM metal-ceramic posterior crowns fabricated from intra-oral digital impressions. Int J Prosthodont 2014;27:331-7.

36. Brawek PK, Wolfart S, Endres L, Kirsten A, Reich S. The clinical accuracy of single crowns exclusively fabricated by digital workflow-the comparison of two systems. Clin Oral Investig 2013;17:2119-25.

37. Seelbach P, Brueckel C, Wöstmann B. Accuracy of digital and conventional impression techniques and workflow. Clin Oral Investig 2013;17:1759-64. 
38. Re D, Cerutti F, Augusti G, Cerutti A, Augusti D. Comparison of marginal fit of Lava CAD/CAM crown-copings with two finish lines. Int J Esthet Dent 2014;9:426-35.

39. Souza RO, Özcan M, Pavanelli CA, Buso L, Lombardo GH, Michida SM, Mesquita AM, Bottino MA. Marginal and internal discrepancies related to margin design of ceramic crowns fabricated by a CAD/CAM system. J Prosthodont 2012;21:94-100.

40. Renne W, McGill ST, Forshee KV, DeFee MR, Mennito AS. Predicting marginal fit of CAD/ CAM crowns based on the presence or absence of common preparation errors. J Prosthet Dent 2012; 108:310-15.

41. Giménez, B, Özcan, M, Martínez-Rus, F, Pradíes G. Accuracy of a digital impression system based on parallel confocal laser technology for implants with consideration of operator experience and implant angulation and depth. Int J Oral Maxillofac Implants 2014;29:853-62.

42. Abdel-Azim T, Zandinejad A, Elathamna E, Lin $\mathrm{W}$, Morton D. The influence of digital fabrication options on the accuracy of dental implant-based single units and complete-arch frameworks. Int J Oral Maxillofac Implants 2014;29:1281-8.

43. Papaspyridakos P, Chen CJ, Gallucci GO, Doukoudakis A, Weber HP, Chronopoulos V. Accuracy of implant impressions for partially and completely edentulous patients: a systematic review. Int J Oral Maxillofac Implants 2014;29:836-45.
44. Stoetzer M, Wagner ME, Wenzel D, Lindhorst D, Gellrich NC, von See C. Nonradiological method for 3-dimensional implant position assessment using an intra-oral scan: new method for postoperative implant control. Implant Dent 2014; 23:612-6.

45. Nickenig HJ, Eitner S. An alternative method to match planned and achieved positions of implants, after virtual planning using cone-beam CT data and surgical guide templates-a method reducing patient radiation exposure (part I). J Craniomaxillofac Surg 2010;38:436-40.

46. Mandelaris GA, Vlk SD. Guided implant surgery with placement of a presurgical CAD/CAM patient-specific abutment and provisional in the esthetic zone. Compend Contin Educ Dent 2014; 35:494-504.

47. Stapleton BM, Lin WS, Ntounis A, Harris BT, Morton D. Application of digital diagnostic impression, virtual planning, and computer-guided implant surgery for a CAD/CAM-fabricated, implantsupported fixed dental prosthesis: a clinical report. J Prosthet Dent 2014;112:402-8.

48. Ender A, Mehl A. Accuracy of complete-arch dental impressions: a new method of measuring trueness and precision. J Prosthet Dent 2013;109:1218.

49. Kattadiyil MT, Mursic Z, AlRumaih H, Goodacre CJ. Intra-oral scanning of hard and soft tissues for partial removable dental prosthesis fabrication. J Prosthet Dent 2014;112:444-8. 


\section{현재 존재하는 구강 스캐너에 대한 고찰}

\section{최종훈 ${ }^{1}$, 임영준 $^{2}$, 이원진 $^{3}$, 한중석 $^{2}$, 이승표 ${ }^{4 *}$}

${ }^{1}$ 서울대학교 치의학대학원

${ }^{2}$ 서울대학교 치의학대학원 치과보철학교실

${ }^{3}$ 서울대학교 치의학대학원 구강악안면방사선학교실

${ }^{4}$ 서울대학교 치의학대학원 구강해부학교실

구강 내의 모습을 재현하는 복제모델을 만드는 것은 치과 진료에서 가장 중요한 과정이며 정확성과 효율성이 동시에 만족되어야 하는 과정이다. 현재 기술이 발전함에 따라 치과 진료에서도 디지털화가 이루어지고 있다. 이러한 것을 가 능하게 하는 가장 중요한 작업 중 하나가 바로 구강 내의 모습을 3차원적으로 재구성하는 디지털화이다. CAD/CAM 시스템의 3가지 성분 (1) data capture component (digitizers), (2) design component (CAD software), (3) manufacturing component (CAM) 중 가장 기본이 되며 뒤의 과정에 막대한 영향을 끼치는 것이 data capture component 즉 구강 스캐 너이다. 이 논문은 Pubmed와 Google Scholar에서 최근 5년 전 연구 논문들을 기초로 하여, 각각의 스캐너의 구동원리 와 스캐너들 간의 정확성, 현재 구강 스캐너가 치과 영역에서 적용되고 있는 분야와 그 정도를 분석하였다.

(구강회복응용과학지 2015;31 (2):112-25)

주요어: 구강 스캐너; 디지털 인상; 3-d 이미지화

*교신저자: 이승표

(110-749) 서울특별시 종로구 연건동 28번지 서울대학교 치의학대학원 구강해부학교실

Tel: 02-740-8671 | Fax: 02-762-6671 | E-mail: orana9@snu.ac. kr

접수일: 2015년 2월 12일 | 수정일: 2015년 5월 15일 | 채택일: 2015년 5월 31일 